\title{
Referral and counter-referral: repercussions of coronary artery bypass graft in the perspective of Primary Care
}

\author{
Referência e contrarreferência: repercussões da revascularização miocárdica na perspectiva da Atenção Primária \\ Referencia y contrarreferencia: repercusiones de la revascularización miocárdica en la \\ perspectiva de la Atención Primaria

\section{Carolina Kahl', Kamylla Santos da Cunha', Gabriela Marcellino de Melo Lanzoni', Giovana Dorneles Callegaro Higashi', Alacoque Lorenzini Erdmann', Maria Aparecida Baggio" \\ ' Universidade Federal de Santa Catarina. Florianópolis, Santa Catarina, Brazil. " Universidade Estadual do Oeste do Paraná. Cascavel, Paraná, Brazil.}

How to cite this article:

Kahl C, Cunha KS, Lanzoni GMM, Higashi GDC, Erdmann AL, Baggio MA. Referral and counter-referral: repercussions of coronary artery bypass graft in the perspective of Primary Care.

Rev Bras Enferm [Internet]. 2018;71(5):2359-66. DOI: http://dx.doi.org/10.1590/0034-7167-2016-0598

Submission: 12-18-2016 Approval: 10-01-2017

\begin{abstract}
Objective: to understand how repercussions of the referral and counter-referral of patients with indication/submitted to Coronary Artery Bypass Graft Surgery in the context of Primary Health Care. Method: qualitative research with a theoretical-methodological contribution anchored in the Grounded Theory. Theoretical sampling was performed with 41 participants, divided into three sample groups (patients, health professionals and managers) in the Metropolitan Region and Western Region of Santa Catarina State. Results: the need for improvement in the process of recording clinical data in the regulation system emerged to strengthen patient referral; and the absence of a formal process of counter-referral and adaptation of lifestyle with repercussion in the counterreferral. Final considerations: the repercussions of the referral and counter-referral of patients with indication/submitted to the CABGS in the context of Primary Care are experienced through professional guidance and, in particular, by family support.

Descriptors: Bypass Graft; Integrality in Health; Referral and Consultation; Public Health Nursing; Primary Health Care.
\end{abstract}

\section{RESUMO}

Objetivo: compreender como são vivenciadas as repercussões do processo de referência e contrarreferência do paciente com indicação/submetido à Cirurgia de Revascularização Miocárdica na Atenção Primária à Saúde. Método: pesquisa qualitativa com aporte teórico-metodológico ancorado na Teoria Fundamentada nos Dados. Alcançou-se a amostragem teórica com 41 participantes, divididos em três grupos amostrais (pacientes, profissionais de saúde e gestores) na Região Metropolitana e Região Oeste de Santa Catarina. Resultados: emergiu a necessidade de melhoria no processo de registro dos dados clínicos no sistema de regulação para fortalecimento da referência do paciente; e ausência de um processo formal de contrarreferência e adaptação do estilo de vida com repercussão na contrarreferência. Considerações finais: as repercussões do processo de referência e contrarreferência do paciente com indicação/submetido à CRM no contexto da Atenção Primária são vivenciadas por meio das orientações profissionais e, em especial, pelo apoio da família.

Descritores: Revascularização Miocárdica; Integralidade em Saúde; Referência e Consulta; Enfermagem em Saúde Pública; Atenção Primária à Saúde.

\section{RESUMEN}

Objetivo: comprender cómo son vivenciadas las repercusiones del proceso de referencia y contrarreferencia del paciente con indicación o sometido a la Cirugía de Revascularización Miocárdica en la Atención Primaria a la Salud. Método: investigación cualitativa con aporte teórico-metodológico anclado en la Teoría Fundamentada en los Datos. Se alcanzó el muestreo teórico con 41 participantes, divididos en tres grupos muestrales (pacientes, profesionales de salud y gestores) en la Región Metropolitana 
y Región Oeste de Santa Catarina. Resultados: surgió la necesidad de mejora en el proceso de registro de los datos clínicos en el sistema de regulación para fortalecer la referencia del paciente; y ausencia de un proceso formal de contrarreferencia y adaptación del estilo de vida con repercusión en la contrarreferencia. Consideraciones finales: las repercusiones del proceso de referencia y la contrarreferencia del paciente con indicación o sometido a la CRM en el contexto de la atención primaria son vivenciadas por medio de las orientaciones profesionales y, en especial, por el apoyo de la familia.

Descriptores: Revascularización Miocárdica; Integralidad en Salud; Referencia y Consulta; Enfermería en Salud Pública; Atención Primaria a la Salud.

\section{CORRESPONDING AUTHOR Carolina Kahl_E-mail: carolinakahl@hotmail.com}

\section{INTRODUCTION}

Cardiovascular Diseases (CVDs) are among the leading causes of death in the world. It is estimated that the $82 \%$ increase in CVDs deaths will occur primarily in developing countries ${ }^{(1)}$. In Brazil, the interest of health managers in investigating ways of controlling and reducing morbidity and mortality and improving the quality of life of patients with CVDS is raising ${ }^{(2)}$.

CVDs can be prevented by reducing and controlling risk factors such as inadequate diet, smoking and sedentary lifestyle, predisposing conditions for chronic diseases such as hypertension and diabetes, which increase the incidence of Myocardial Infarction (MI) and consequent indication of Coronary Artery Bypass Graft Surgery (CABGS). In the finding of $\mathrm{MI}$, when there is a problem of access to treatment considered gold standard - percutaneous coronary intervention in a timely manner - CABGS is one of the therapeutic possibilities indicated for the complications associated to CVDs, extending the life expectancy of patients, providing physical, and emotional comfort and improvement in quality of life ${ }^{(3)}$.

Patient care with CABGS indication requires integration between different points from Health Care Network (RAS) to Primary Health Care (PHC) through individual and collective actions aimed at health promotion, disease prevention, diagnosis, treatment and rehabilitation, to the services offered in the hospital ${ }^{(4)}$. The complexity of CABGS requires the careful attention of health professionals, from the initial clinical evaluation of signs and symptoms, requesting diagnostic tests, to surgical indication, postoperative period and rehabilitation, observing the patient in an integral and longitudinal way ${ }^{(5)}$. In this process, the clinical practice performed by professionals, especially by nursing, regarding the implications for specific care in this area, as well as acting at all stages of the evolution of the disease, can provide support for prevention, promotion and rehabilitation through articulated actions to guarantee the integral care to the patient, which include individual consultations and actions of an organizational character of coordination, and evaluation of the care to the people, family and community ${ }^{(6)}$.

The National Regulatory System (SISREG), responsible for the articulation of health services in the SAR, is highlighted as a management tool aimed at the organization of these, aiming to ensure the integral health care of individuals through the referral and counter-referral process, which consists of the organization of health services through criteria, referral flows and pacts that guide the individual's walk through the network ${ }^{(7)}$. However, difficulties are faced for the full development of the integrality and coordination of care, such as the absence of an integrated and regionalized network of referral and counter-referral of the patient with indication/submitted to the CABGS, which can have repercussions in the health- disease, interfering with their care and sometimes even aggravating their clinical condition ${ }^{(8)}$.

Therefore, the development of this study is justified due to the identification of gaps in the care flow and the need to offer a structured referral and counter-referral network with a view to completeness of assistance to the individuals with indication/ submitted to the CABGS, respecting the principles and guidelines proposed by the Brazilian Unified Health System (SUS), as well as the need for improved communication between PHC health professionals and SISREG operators.

\section{OBJECTIVE}

This is study aims to understand how repercussions of the referral and counter-referral process of the patient with indication/submitted to the CABGS in PHC are experienced.

\section{METHOD}

\section{Ethical aspects}

The study complied with the ethical precepts of Resolution 466/12 of the National Health Council (CNS), being approved by the Research Ethics Committee with Human Beings of the Universidade Federal de Santa Catarina. In order to guarantee the confidentiality and anonymity of the participants, the letter E followed by the number corresponding to the order of the interviews to designate them (E1, E2, E3 ...) and the indication of the sample group - first group (G1), second group (G2), third group (G3) - as follows: (E1G1); (E1G2); (E1G3).

\section{Theoretical-methodological framework}

The Grounded Theory, which seeks to understand social phenomena, is explored as a theoretical-methodological framework, with an emphasis on relational processes and an intimate relation with the logic of the process of referral and counter-referral, exploring their meaning from the interrelationship between the data, as well as the constant comparative analysis ${ }^{(9)}$.

\section{Type of study}

This is a qualitative study, based on the deepening of the data derived from the "Consequences" component, inherent to the paradigm model of the Grounded Theory ${ }^{(9)}$, where, given its relevance to the understanding of the phenomenon, 
it was decided to deepen the discussion and give visibility to the findings.

\section{Methodological procedures}

This is a part of the research project entitled "Patient who underwent coronary artery bypass graft: Referral Process and Counter-Referral of Health Services of Santa Catarina", which presents the phenomenon "Emerging high complexity as a referral for a person submitted to Coronary Artery Bypass Graft Surgery due to the fragility of Primary Health Care in the followup and articulation with the other levels of care in the SUS".

\section{Study setting}

The study setting comprised two poles in the Santa Catarina State near the Basic Health Units (BHU) of two municipalities, one in the Metropolitan Region and the other in the Western Region, known as a reference in cardiovascular care in the state capital and state, respectively.

\section{Data source}

The theoretical sample of this study was reached with 41 participants, divided into three sample groups subdivided into 14 patients, 21 health professionals and six health managers, totaling 25 in the Metropolitan Region and 16 in the Western Region. Patients selected for the study were indicated by PHC professionals. The selection of professionals was intentional and obeyed the following strategy: each participating professional indicated a new professional, who was invited to participate in the research and, according to his/her availability, the researcher conducted the interview. The theoretical sampling in the Grounded Theory consists of the composition of the sample from the data collection of places and people that will best answer the research question, providing a range of information that helps the development of concepts, as well as revealing and identifying the relationships and interactions between these concepts ${ }^{(9)}$.

\section{Collection and data organization}

The collection took place between March and June of 2014, with open and individual interviews conducted by the research team of the project, at the place of choice of the participant (place intended for the work environment with professionals and at home with patients). The interviews had an average duration of 30 minutes and were recorded using a digital audio recording device and later transcribed in full for the analysis process.

The first sample consisted of 14 patients identified by PHC health professionals who met the criteria for inclusion: adults, regardless of gender, who had been submitted to CABGS for at least six months and if they were at home at the time of the interview. The first contact was at $\mathrm{BHU}$, after the clarifications regarding the ethical aspects and the agreement to participate in the research. The interview was held at BHU itself, in a place intended for the study, or at the participant's house at the client's preferred time. For this group, the following guiding questions were adopted: "Tell me, how was your PHC health follow-up until the CABGS?" And "Tell me, how was your surgical experience and consequences faced after the CABGS?". From the answers to the initial questions, new questions were directed in order to meet the purpose of the study.
Participants emphasized the professional support of the health team regarding the orientation of access to services for CABGS in the process of referral and counter-referral. Therefore, it was decided to follow the second sample group in order to deepen questions relevant to the professional performance.

Twenty-one professionals participated in the second group, eight nurses, six physicians and seven community health agents who met the inclusion criteria adopted: being linked to PHC; and have been with BHU for at least six months. To begin the interviews, the guiding question was "How do you promote the health follow-up of patients with indication/submitted to CABGS?".

From the answers of the participants to these questions, it was observed that the regulatory system plays a fundamental role in the process of referral and counter-referral. Therefore, it was decided to create a third sample group with participants who could best answer the key questions about the regulation system in this process. This group was composed of six professionals; of these, three were linked to SISREG in the metropolitan region, two physicians and one administrative technical professional, and three were professionals linked to the Municipal Health Reference Center (CRESM) in the Western Region, one physician and two nurses. As inclusion criterion, professionals linked to the SISREG and the CRESM acting for at least six months were adopted. The question that guided the interviews for this group was "How did the municipal regulation contribute to the process of referral and counter-referral of the person submitted to the CABGS?". Thus, the importance of the clinical practice of health professionals for the correct filling and proper referral of the patient with CVDs with indication to the CABGS in the different points of the RAS was emphasized.

The exclusion criteria were: in the first sample group, patients younger than 18 years or without clinical conditions to respond to the interview, and for the other groups, professionals who were away from work during the data collection period. The theoretical saturation of the data, as recommended by the Grounded Theory, was defined by the absence of new elements relevant to the data analysis and consolidation of categories and subcategories in their properties and dimensions, thus finalizing the theoretical sampling of this study with three sample groups.

\section{Data analysis}

The analysis took place in three interdependent stages, according to the Grounded Theory's theoretical and methodological framework. The first one consisted of open coding, where the concepts were identified and their properties and dimensions were discovered. In the axial codification, second stage, the subcategories established a relationship with the categories in order to obtain a more complete explanation about the phenomenon, its properties and dimensions. And, in the third stage, selective coding, the linking of categories around a central category occurred, in order to reduce and improve the theory ${ }^{(9)}$. NVIVO ${ }^{\circledR}$ software was used to aid in the ordering and organization of data in the coding process.

In the analysis, it was possible to identify the categories that support the phenomenon of the study, presenting here the category referring to the "Consequences" component, entitled "Realizing family support, the need to intensify professional 
orientations, discontinued PHC follow- cardiac rehabilitation, still under-structured, as important repercussions on referral and counter-referral, "with two subcategories: "Highlighting the need for improvement of clinical practice in PHC for strengthening the referral of the patient with CVDs and indication of CABGS" and "offered at the PHC for rehabilitation and lifestyle adaptation with repercussion in the counter-referral".

\section{RESULTS}

The category "Revealing the repercussions of the referral and counter-referral process of the patient with CVDs/indication of CABGS" adds important elements of the complex flow and counter-flow of patients with CVDs in health services.

The first subcategory, "Highlighting the need for improvement of clinical practice in $\mathrm{PHC}$ for strengthening the reference of the patient with CVDs and indication of CABGS", points out that patients affected by CVDs seek the hospital emergency in front to acute events, due to the rapid care, however, in case of stability in the clinical setting, they are advised to seek the $\mathrm{BHU}$ to give continuity to the care. When the patient is being followed up at the PHC, after clinical evaluation of the health team and collection of information necessary for diagnostic hypothesis, the patient is referred to the PHC via SISREG.

The PHC team makes a referral with the patient's information that is inserted by a technical and administrative professional from the PHC in this system [SISREG] via internet. (E38G3)

The participants pointed out that the fact that the clinical information of the patient evaluated by the health care professional was completed manually makes it difficult for the system operator to understand the PHC because, in addition to not understanding what was written, there is no training in the health area. If it were not a manuscript, it would facilitate their understanding, as illustrated by the following speech.

It would be better if it were not manuscript, because it will go to another person from another area without the required knowledge on it [...] they are technical terms, it takes more time to someone from another area to search, as the physician is not there sometimes to make clarifications. (E36G3)

In some cases, it is necessary to contact the regulator directly by e-mail to clarify questions related to CVDs patient referral process. The slowness in this process ends up impacting on pending and the PHC overload.

It was through telephone [the contact with SISREG], but it got very busy, so now it's by email and the answer is not immediate, unfortunately. So you have that situation pending at the health center. (E36G3)

SISREG aims to order and prioritize routing requests based on clinical situations rather than on chronological situations, as it was before the system was deployed. The requests that arrive to the central of regulation are evaluated by professionals, in particular physicians, who effectuate the referral to another sector according to the information of the clinical picture of the patient. However, requests for referrals with a shortage of clinical information become a common practice, causing these requests to return to $\mathrm{PHC}$ requesting more information, which, consequently, implies delays in the referral process of patient with CVDs.

I send many [requests] back, because it is not described and needs some physical examination data, a diagnostic hypothesis of what was performed in the examination. You need to give me an idea of what's going on because I can't see the patient. (E38G3)

Some nurses affirm that they feel more confident in guiding patients with CABGS indication because of the previous experience of working in cardiology, which has promoted the improvement of their clinical practice. The guidelines are not only intended for the patients, but also for the family members who will accompany them throughout the process.

Before, who used to give the guidelines to the patient on the surgery was the physician, nowadays $i$ am the one who do it due to my experience with cardiology [...]. We also carried out guidelines for family members [...] I advise on all preoperative, intraoperative and postoperative procedures. (E16G2)

According to the patients' reports, the guidelines received from the professionals are indispensable for achieving the desired results, providing quality of life after the surgical experience. The competence and clinical practice of the PHC professionals allowed an integral and continuous care to the patients with CVDs. With the mastery of the specific clinical knowledge, the professional is capable of providing a qualified care to these patients, with appropriate treatment and guidance, and allows an extended look at emotional and affective issues that permeate the surgical process and its repercussions, such as fear and anxiety. In addition, spirituality and religious beliefs can comfort and give hope to the patient and their families.

Regarding the counter-referral process, the second subcategory, entitled "Highlighting the non-existence of a formal process of counter-referral to PHC and difficulties in adapting to cardiac rehabilitation", revealed that, after discharge, the patient is instructed to seek the outpatient clinic for the first consultations, maintaining the bond with these professionals. Then the patient goes on to the follow-up at PHC, which sometimes occurs concomitantly with outpatient visits. However, patients are not formally counter-referred to PHC as this follow-up is usually requested by family members.

She has undergone Coronary Artery Bypass Graft Surgery and after discharge began to be attended there with the cardiologist [in the hospital] and came here [PHC] to have a parallel follow-up. (E25G2)

We find out that the patient did the surgery when the person or a relative comes here $[\mathrm{PHC}]$ and inform us. (E17G2)

Relatives say that the patient was discharged from the hospital and has difficulty in coming to the $\mathrm{BHU}$, so we go to the person's home [...] the family is always a good support 
network, they [family members] help a lot and I find it fundamental. (E21G2)

The findings indicate that most families are present at the postoperative follow-up, receiving the patient's discharge guidelines, giving assistance and follow-up to the cardiac rehabilitation service and requesting a home visit at PHC.

While some patients stated that they followed the guidelines after surgery at the hospital and at PHC, others, even aware of the importance of these changes, reported not performing light physical activities, such as walking, for example, or adopting adequate diet, smoking cessation, as follows:

Food, I can't eat too much, they have guided me, what I eat most is light foods, sweeteners, light yogurts [...] I buy only these things. (E6G1)

I stopped smoking after the surgery for four months, after that I've already tried three treatments to quit but I failed in doing so. (E1G1)

Among the recommendations after CABGS, there is cardiac rehabilitation, which happens at the outpatient level in the reference hospital for CABGS in the metropolitan and Western Regions of the State. When the patient was not referred from the hospital to a rehabilitation service, the PHC itself makes the referral, according to the following speech.

Usually, they [post-CABGs patients] are either referred to the rehabilitation service, or, if they were not referred from the hospital, we $[\mathrm{PHC}]$ ended up directing the patient. (E21G2)

In the counter-referral, some of the patients interviewed had difficulties in maintaining the follow-up of cardiac rehabilitation due to financial issues to go to the hospital periodically, ending up interrupting the treatment. They also associated the impossibility of returning to work with the interruption of cardiac rehabilitation activities, due to the limitations that the CABGS initially caused.

I participated [at the cardiac rehabilitation] several times, but over time I was forced to stop because of my financial situation. It's far; I depend on buses to commute. (E1G1)

In addition to cardiac rehabilitation, other activities can be performed by patients after CABGS and offered by PHC, such as physical activity and walking groups, performed with the assistance of a professional. However, some participants indicated that they did not receive guidelines to participate in these activities. On the other hand, the professionals interviewed emphasized that they advised on the importance of participation in these activities.

The physician never asked me to participate in walking groups, not that I remember. (E5G1)

There is also the physical activity group, which is gradually introducing the patient into their normal activities [after CABGS], which is end up referred to them. (E16G2)
A differential in the Western Region of Santa Catarina State consists of the Cidade do Idoso (freely translated as Elderly City) program. Patients, after meeting this program, seek the PHC to be referred, however, although some professionals are being referred, there is still little guidance on how to actually proceed to participate in the activities offered in the program.

I don't refer anyone to the Elderly City due to little information, the patients go spontaneously. There is a physician, a nurse, a physical educator [...]. (E29G2)

At that time [before the CABGS] I didn't use to do any physical exercise, after I started doing here in the Elderly City [...]. I do bodybuilding. In the beginning, I did Pilates, a year later I did swimming, whirlpool [...]. I like there a lot. (E9G1)

The Elderly City emerges as an alternative for patients seeking the practice of physical exercise after the CABGS, in view of the diversity of activities, such as gymnastics, dancing and sports, concentrated in a single place, in addition to the assistance of health professionals.

\section{DISCUSSION}

From the study, the contribution of the research can be evidenced in relation to the production of new knowledge and elements of the referral and counter-referral process, which may facilitate or even make feasible the implementation of care flow to the patient with CVDs. Thus, as innovative aspects, it is evident the need to expand the domains of specific clinical knowledge by the PHC professional, which converges with the vogue theme of advanced nursing practice. It is also pointed out that in the counter-referral process the family was active in the guidance search process, considering the inefficiency of the system. Also, the rehabilitation process is identified as an important action to the continuity of care, besides being configured as a gap to be explored by the nurse that reinforces its competence for prevention, promotion, recovery and rehabilitation of the patient under an integral, humanized and longitudinal perspective.

Although PHC is recommended as an entry point for individuals to health services and some participants in this study have sought out the PHC for the first time, the demand for the hospital emergency against acute events is underscored in the understanding that this care will be faster. Studies have identified among the reasons for users' spontaneous search for the emergency service, the agility in care and the greater severity of health conditions. In addition, some of these patients were not referred by other services, such as PHC or emergency care unit, to resolve cases ${ }^{(10-11)}$, which shows the fragile interlocution between the different points of RAS, as well as clinical practice, when assessing the signs and symptoms of the patient and follow their referencing.

The above information differs from what is recommended by the health system regarding the PHC to welcome patients from its territory, coordinating the care and ordering the RAS, in addition to providing access to health services of greater technological complexity, appropriate in its longitudinality/ 
continuity of the care ${ }^{(12)}$. In addition, if the acute symptoms presented are of clinical severity, the search for these patients by the specialized attention with appropriate technological back-up is not excluded.

The need for a thorough evaluation that articulates the technical knowledge of the profession to the knowledge generated in the experience to evaluate the clinical information and to trace the plans and to perform the appropriate care interventions ${ }^{(13)}$ reflect in the care to the patient with indication/submitted to the CABGS transit through the different points of RAS, especially when it is necessary to interface with SISREG.

With regard to SISREG, greater attention is paid to its filling process, since it implies a delay in referencing patients in the network. A study carried out in the city of Rio de Janeiro identified double queries for specialized services, possibly caused by system failures or oscillation in the transmission of data over the Internet, as well as operator error handling ${ }^{(14)}$. which results in implications in the referral process of the individual with indication of CABGS and consequent worsening of his clinical condition until he arrives at a specialist and to the surgical referral.

Another element highlighted by the participants refers to the guidelines that patients with surgery and family members receive about the $\mathrm{CABGS}$. In particular, nurses involved in $\mathrm{PHC}$ care management in receiving these patients should be active agents, guiding them about the procedures and the care settings they must undergo ${ }^{(15)}$. It is confirmed that the guidelines for CABGS performed by the nurse and the preoperative patient help in the full understanding of the surgery, clarifying doubts and preparing it physically and psychologically for the surgical experience and the importance of the adequate follow-up of the treatment in each step of this process ${ }^{(16)}$. Emphasizing, therefore, a clinical practice mediated by professional skills, knowledge and skills that value existing social and historical contexts ${ }^{(17)}$.

The relatives are also evidenced in the confrontation of the surgical process of these patients, receiving, along with the indication of CABGS, the guidelines. The family system is reported in a study with people submitted to the CABGS as the main source of support reported by the patients, confirming through the reports that the direct assistance of the family in the accomplishment of domestic activities and self-care, accompaniment and emotional support are fundamental throughout the treatment, and rehabilitation after hospital discharge ${ }^{(18)}$.

Regarding the feelings experienced when receiving the indication of CABGS until the moment of hospitalization, the results bring specificities, since some patients refer anxiety and fear while others report tranquility, relying on their spirituality. Converging to this assertion, a study confirms that in the preoperative period there is an ambiguity of feelings, verbalizing contradictorily anxiety, fear, tranquility and anguish ${ }^{(15)}$. The competence of the professionals reflected in the quality of the care, together with the spirituality of the patients, unite to obtain positive results consequent to the surgical experience ${ }^{(19)}$.

After the CABGS, the patients remain the first hospitalized days receiving the initial guidelines and, after discharge, followup visits at the hospital outpatient level, concomitantly with the $\mathrm{PHC}$, with the health professionals, in the counter-referral. The continuity of care in and out of the hospital stands out positively for the reduction in the number of hospital readmissions after $\mathrm{CABGS}^{(20)}$ and consequent improvement and stability in the clinical picture of these patients.

Some patients still have difficulties in adapting to the necessary changes in their lifestyle. Corroborating this finding, a study aimed at understanding the meanings of the patients' living process after the CABGS identified difficulties and limitations regarding the new lifestyle, such as dietary restrictions, the need to practice physical activity and work abandonment due to physical limitations ${ }^{(21)}$.

The CABGS also brings the need to follow a therapy with medicine, which can be acquired through different means. A large part of this population uses the SUS as a source for obtaining medicines, either by PHC pharmacies and polyclinics, SUS pharmacies or by the Programa Farmácia Popular (freely translated as Popular Pharmacy Program) ${ }^{(22)}$, where accredited medications can be purchased by patients on prescription at a price of cost or free of charge ${ }^{(23)}$.

Regarding changes in lifestyle, cardiac rehabilitation is a set of activities necessary to achieve changes in lifestyle, with emphasis on scheduled physical activities, adoption of healthy eating habits, smoking cessation, and ${ }^{(24)}$, improving the functional capacity of patients undergoing CABGS. It is recommended that cardiovascular rehabilitation programs be structured and implemented in both the public and private services, with activities carried out in an integral structure of the hospital complex, but some activities may be performed in another environment suitable for physical exercise, such as clubs sports, sports gyms, etc. ${ }^{(25)}$.

That said, rehabilitation represents a crucial phase in the recovery of patients submitted to the CABGS, who, at the end of the whole process, must be able to achieve permanent changes in their life, adopting healthy daily habits and controlling risk factors, avoiding the emergence of new diseases or recurrences. Studies show that adherence of patients submitted to CABGS to rehabilitation activities present significant hemodynamic, metabolic, vascular, alimentary and psychological changes associated with a better control of coronary risk factors and improvement of quality of life ${ }^{(24,26)}$.

As a consequence of the CABGS in the counter-referral, some participants pointed out that there is no continuity in cardiac rehabilitation activities. A literature review has shown that the increased risk of mortality in CVDs patients is associated with the time spent with sedentary lifestyle and that a controlled increase in physical activity can minimize this risk ${ }^{(27)}$ and contribute to the recovery of patients submitted to CABGS. In addition, another study showed that the practice of physical exercises in PHC accompanied by professionals interfered positively in the use of the health services by the population, the users perceived themselves to be healthier, they increased the effectiveness in the control of the blood pressure and they reduced the frequency of routine visits to the $\mathrm{PHC}^{(28)}$.

The Western Region of Santa Catarina State also has the Elderly City, which acts with a proposal to expand the health care of the elderly, providing in a single place access to health care with professionals in medicine, nursing, physical therapy, 
physical education and nutrition; physical activities in gym and water aerobics; as well as other leisure activities such as crafts, dances and moments of interactions with other people ${ }^{(29)}$. Thus, the participants of the study positively visualized the insertion in the Elderly City as a consequence of the surgical experience in the counter-referral process, representing a strong stimulus of adherence to a new lifestyle, besides the practice of physical exercises with accompaniment of professionals, leisure activities and socializing with other people in similar situations, promoting the quality of life of these people and, consequently, decreasing the chances of CVDs relapse.

\section{Study limitations}

The study was limited in providing data of the Metropolitan Region and West Region of Santa Catarina State, in the context of PHC, allowing the understanding of the referral and counter -referral process and the patient with indication/submitted to CABGS in these settings. Although they are two great poles of health care and reference in cardiology in Santa Catarina State and present specific features related to the flow of patients, it was possible to show similar challenges in the counter-referral process.

\section{Contributions to the nursing sector}

The study provides subsidies for professionals and health managers to improve Primary Care, as a gateway to the RAS that refers patients with CVDs/risks to the various points of attention of the network, but which has structure and health professionals and skilled nursing staff to follow patients that underwent Coronary Artery Bypass Graft Surgery up, when counter-referred. To do so, it is necessary to expand the nurse's role in the PHC to consolidate the link with SUS users.

\section{FINAL CONSIDERATIONS}

It was possible to understand that the repercussions of the referral and counter- referral process of the patient with indication/submitted to the CABGS, in the context of PHC in the Metropolitan and Western Regions of Santa Catarina State, are experienced through the guidance of professionals and, in particular, family. In the referral, it was evidenced the need for improvement in the process of recording the clinical information of the patients in the $\mathrm{PHC}$ regulation system, so as to strengthen the referral of the patient with CVDs, so that there is continuity to their care in the network flow.

In the counter- referral, discontinued follow-up was identified in the PHC, in the identification of patients who were discharged from hospital and were in their homes, due to the absence of a formal process of counter-referral of these patients to PHC, highlighting the family in the search for care in this sector.

\section{FUNDING}

This study had financial support from the Foundation for Research and Innovation Support of the Santa Catarina State (FAPESC) through the process 1459/2012.

\section{REFERENCES}

1. World Health Organization-WHO. Cardiovascular Diseases-CVDs[Internet]. Geneva: WHO; 2016[cited 2016 Aug 22]. Available from: http://www.who.int/mediacentre/factsheets/fs317/en/

2. Schmidt MI, Duncan BB, Mill JG, Lotufo PA, Chor D, Barreto SM, et al. Cohort Profile: longitudinal study of adult health (ELSABrasil). Int J Epidemiol[Internet]. 2015[cited 2017 Jul 26];44(1):68-75. Available from: https://www.ncbi.nlm.nih.gov/pmc/articles/ PMC4339754/pdf/dyu027.pdf

3. Colósimo FC, Sousa AG, Silva GS, Piotto RF, Pierin AMG. Hipertensão arterial e fatores associados em pessoas submetidas à cirurgia de revascularização do miocárdio. Rev Esc Enferm USP[Internet]. 2015[cited 2017 Jul 26];49(2):201-8. Available from: http://www.redalyc.org/pdf/3610/361038470003.pdf

4. Marcolino MS, Brant LCC, Araújo JG, Nascimento BR, Castro LRA, Martins P, et al. Implantação da linha de cuidado do infarto agudo do miocárdio no município de Belo Horizonte. Arq Bras Cardiol[Internet]. 2013[cited 2016 Aug 23];100(4):307-14. Available from: http://www.scielo.br/pdf/abc/2013nahead/aop5145.pdf

5. Borges DL, Nina VJS, Lima RO, Costa MAG, Baldez TEP, Santos NP, et al. Características clínicas e demográficas de pacientes submetidos à revascularização do miocárdio em um hospital universitário. Rev Pesqui: Saúde[Internet]. 2013 [cited 2016 Aug 23];14(3):171-4. Available from: http://www.scielo.br/pdf/rbccv/v27n1/v27n1a09.pdf

6. Costa RHS, Couto CRO, Silva RAR. Prática clínica do enfermeiro na Estratégia de Saúde da Família. Saúde[Internet]. 2015[cited 2017 Jul 26];41(2):9-18. Available from: https://periodicos.ufsm.br/revistasaude/article/download/10841/pdf

7. Costa SM, Ferreira A, Xavier LR, Guerra PNS, Rodrigues CAQ. Referência e contrarreferência na saúde da família: percepções dos profissionais de saúde. Rev APS[Internet]. 2013[cited 2016 Aug 23];16(3):287-93. Available from: https://aps.ufjf.emnuvens. com.br/aps/article/view/1888

8. Cunha KS, Higashi GDC, Erdmann AL, Kahl C, Koerich C, Meirelles BHS. Myocardial revascularization: factors intervening in the reference and counter-reference in Primary Health Care. Rev Esc Enferm USP[Internet]. 2016[cited 2017 Jul 26];50(6):963-70. Available from: http://www.scielo.br/pdf/reeusp/v50n6/pt_0080-6234-reeusp-50-06-00965.pdf

9. Strauss A, Corbin J. Pesquisa qualitativa: técnicas e procedimentos para o desenvolvimento de teoria fundamentada. Rocha LO, (Trad.). $2^{\mathrm{a}}$ ed. Porto Alegre: Artmed; 2008. 
10. Freire AB, Fernandes DL, Moro JS, Kneupp MM, Cardoso CM, Lima SBS. Serviços de urgência e emergência: quais os motivos que levam o usuário aos pronto-atendimentos? Saúde[Internet]. 2015[cited 2017 Jul 26];41(1):195-200. Available from: https:// periodicos.ufsm.br/revistasaude/article/view/15061/pdf

11. Martins JAF, Franco SC. Condições cardiológicas sensíveis à atenção primária em serviço terciário de saúde: apenas a ponta do iceberg. Saúde Debate[Internet]. 2013[cited 2016 Aug 28];98(37):388-99. Available from: www.scielo.br/pdf/sdeb/v37n98/a03v37n98.pdf

12. Oliveira MAC, Pereira IC. Atributos essenciais da Atenção Primária e a Estratégia Saúde da Família. Rev Bras Enferm[Internet]. 2013[cited 2016 Aug 28];66(Esp):158-64. Available from: www.scielo.br/pdf/reben/v66nspe/v66nspea20.pdf

13. Machado MLP, Oliveira DLLC, Manica ST. Consulta de enfermagem ampliada: possibilidades de formação para a prática da integralidade em saúde. Rev Gaúcha Enferm[Internet]. 2013[cited 2016 Aug 28];34(4):53-60. Available from: http://www.scielo. br/pdf/rgenf/v34n4/07.pdf

14. Ceciliano TM, Duque PHC, Nascimento GE. Duplicidades em marcações de consultas pelo Sistema Nacional de Regulação SISREG. Acad Rev Científ Saúde[Internet]. 2016[cited 2016 Aug 28];1(1):1-8. Available from: http://smsrio.org/revista/index.php/ reva/article/view/127

15. Bessa ATT, Mesquita MRM, Stipp MAC. Saúde do homem e doença cardiovascular: gerenciamento do cuidado de enfermagem em nível ambulatorial. Rev Pesqui: Cuid Fundam[Internet]. 2016[cited 2017 Jul 26];8(3):4766-72. Available from: http://www.seer. unirio.br/index.php/cuidadofundamental/article/view/3954

16. Coppetti LC, Stumm EMF, Benetti ERR. Considerações de pacientes no perioperatório de cirurgia cardíaca referentes às orientações recebidas do enfermeiro. Rev Min Enferm[Internet]. 2015[cited 2016 Sep 14];19(1):113-9. Available from: http://www.reme.org. br/artigo/detalhes/990

17. Silveira LC, Vieira AN, Monteiro ARM, Miranda KCL, Silva LF. Clinical care in nursing: development of a concept in the perspective of professional practice reconstruction. Esc Anna Nery Rev Enferm[Internet]. 2013[cited 2017 Jul 26]; 17(3):548-54. Available from: http://www.scielo.br/pdf/ean/v17n3/en_1414-8145-ean-17-03-0548.pdf

18. Bin G, Costa MCS, Vila VSC, Dantas RAS, Rossi LA. Significados de apoio social de acordo com pessoas submetidas à revascularização do miocárdio: estudo etnográfico. Rev Bras Enferm[Internet]. 2014[cited 2016 Sep 14];67(1):71-7. Available from: http://www. scielo.br/pdf/reben/v67n1/0034-7167-reben-67-01-0071.pdf

19. Lanzoni GMM, Higashi GDC, Koerich C, Erdmann AL, Baggio MA. Fatores que influenciam o processo de viver a revascularização cardíaca. Texto Contexto Enferm[Internet]. 2015[cited 2016 Sep 14];24(1):270-8. Available from: www.scielo.br/pdf/tce/v24n1/ pt_0104-0707-tce-24-01-00270.pdf

20. Hall MH, Esposito RA, Pekmezaris R, Lesser M, Moravick D, Jahn L. Cardiac surgery nurse practitioner home visits prevent coronary artery bypass graft readmissions. Ann Thorac Surg[Internet]. 2014[cited 2016 Sep 14];97:1488-95. Available from: https://www. ncbi.nlm.nih.gov/pubmed/24612701

21. Callegaro GD, Koerich C, Lanzoni GMM, Baggio MA, Erdmann AL. Significando o processo de viver a cirurgia de revascularização miocárdica: mudanças no estilo de vida. Rev Gaúcha Enferm[Internet]. 2012[cited 2016 Sep 14];33(4):149-56. Available from: http://www.scielo.br/pdf/rgenf/v33n4/19.pdf

22. Mengue SS, Tavares MUL, Costa KS, Malta DC, Silva Jr. JB. Fontes de obtenção de medicamentos para tratamento de hipertensão arterial no Brasil: análise da Pesquisa Nacional de Saúde, 2013. Rev Bras Epidemiol[Internet]. 2015[cited 2016 Sep 14];18(Suppl-2):192-203. Available from: www.scielo.br/pdf/rbepid/v18s2/1980-5497-rbepid-18-s2-00192.pdf

23. Brasil. Ministério da Saúde. Programa Farmácia Popular do Brasil: Manual de informações às unidades credenciadas: sistema de co-pagamento. 2008; 2 ed. 22p.

24. Sociedade Brasileira de Cardiologia. Diretriz Sul-americana de prevenção e reabilitação cardiovascular[Internet]. 2014 [cited 2016 Sep 14];103(2). Available from: http://publicacoes.cardiol.br/2014/diretrizes/2014/Diretriz_de_Consenso\%20Sul-Americano.pdf

25. Diretriz de Reabilitação Cardíaca. Arq Bras Cardiol[Internet]. 2005[cited 2016 Sep 14];84(5):431-40 Available from: http://www. scielo.br/pdf/abc/v84n5/a15v84n5.pdf

26. Magalhães S, Viamonte S, Ribeiro MM, Barreira A, Fernandes P, Torres S, et al. Efeitos a longo prazo de um programa de reabilitação cardíaca no controlo dos fatores de risco cardiovasculares. Rev Port Cardiol[Internet]. 2013 [cited 2016 Sep 14];32(3):191-9 Available from: http://www.elsevier.pt/pt/revistas/revista-portuguesa-cardiologia-334/pdf/S087025511200306X/S300/

27. Chau JY, Grunseit AC, Chey T, Stamatakis E, Brown WJ, Mathews CE, et al. Daily sitting time and all-cause mortality: a meta-analysis. Plos One[Internet]. 2013[cited 2016 Sep 14];8(11)1-14. Available from: http://journals.plos.org/plosone/article?id=10.1371/ journal.pone.0080000

28. Giraldo AED, Gomes AEO, Serafim THS, Zorzeto LP, Aquino DC, Kokubun E. Influência de um programa de exercícios físicos no uso de serviços de saúde na Atenção Básica de Saúde do município de Rio Claro, SP. Rev Bras Ativ Fis Saúde[Internet]. 2013[cited 2016 Sep 14];18(2):186-96 Available from: https://periodicos.ufpel.edu.br/ojs2/index.php/RBAFS/article/viewFile/2624/pdf66

29. Oliveira PP, Verffel A, Antoniolli MA, Silveira MT, Parmeggiani SP, Correio GPG. Vida segura para o idoso: interação entre atividades teórico práticas e pesquisa científica em um projeto de extensão. Interfaces Rev Ext[Internet]. 2014[cited 2016 Sep 14];2(2):131-42 Available from: https://www.ufmg.br/proex/revistainterfaces/index.php/IREXT/article/viewFile/.../pdf 